\title{
Does Push Factor Determine Capital Flow to Emerging Markets during Financial Crisis?
}

\author{
Rido Tanago*, Munawar Ismail, Ghozali Maski and Devanto Shasta Pratomo
}

Univeristy of Brawijaya, Malang, Indonesia

\begin{abstract}
The objective of this study is to investigate what determinant factors affecting capital flow to Emerging markets (EMEs) during Global Financial Crisis (GFC). Whether push factors as external factors or pull factors as domestic / internal factors and what is the most dominant variable using study of literature method. The method used in this study is review of literature, firstly investigate five previous literatures on Latin America and Asia crises and then focus on six main literatures that related to GFC. The findings show the determinant factors affecting capital flow to EMEs during GFC are push factors with world interest rate and global risk condition as main or dominant variables during 2007-2009 episode. Push factors are determinant factors and world interest rate and global risk appetite are dominant variables.
\end{abstract}

Keywords: Push factor; Pull factor; Capital flow; Emerging market; Financial crisis

\section{Introduction}

Foreign capital flows provide important and substantial benefits to the development of one country. Capital inflows are one of key sources of funds for Emerging Market Economies (EMEs) to sustain their economic development. However the volatility of capital flow may have widespread economic consequences, amplifying economic cycles, increasing financial system vulnerabilities, and disturbing overall macroeconomic stability. Global capital flow had steadily increased from less than 7\% of world GDP in 1998 to more than 20\% in 2007, led in particular by a dramatic expansion of flows to and from Advance Economies (AEs). But these capital flows decreased during 2007-2009 Global Financial Crisis (GFC), the GFC brought a sudden stop to the sustained rise in international financial integration over the past decade.

To confirm that there are few research findings such as study by the IMF (2016) concentrates on the decline in net capital inflows to EMEs since 2010 which can be attributed to both weaker gross capital inflows and stronger gross capital outflow. Bussiere et al. (2016) also finds a detailed account of the persistent decline in global capital flows in particular among AEs since GFC. In related to capital flow Milesi-Ferretti and Tille (2011) state that a number of factors determining the pre-crisis growth in international capital flows such as Euro area financial integration, financial deepening in AEs associated with increases in financial balance sheets as well as international portfolio diversification. Moreover, efforts aimed at reforming banking and financial regulation could also inhibit a recovery in banking flows. But reversely, Bremus and Fratzscher (2015) show that changes in regulatory policy, notably increases in supervisory power or independence, have encouraged credit outflows since the crisis. Similarly, research by Cerutti et al. (2015) find a close link between macroprudential policy measures, credit growth and cross-border borrowing.

In 2007-2009 GFC occurred, triggered by a real estate bubble arising from misused subprime mortgage. Then the US recession happened. The Federal Reserve (The Fed) starts to stimulate economic activity by increasing aggregate demand, which is to reduce short-term interest rates and open market operations, namely buying treasury bills. However, at the interest near zero (zero lower bound), the open market operation still not effective, then The Fed decided to apply Unconventional Monetary Policy (UMP), by purchasing long-term assets in large quantities, known as Large Scale Assets Purchase (LSAP). LSAP also called Quantitative Easing (QE) can increase money supply but not all funds absorbed by US domestic investment. Then excess funds goes 
abroad, the largest amount goes to EMEs. This capital inflow has stimulated the EMEs' capital markets reflected in increasing the EMEs' portfolio investment (Saghian and Reed 2015. Sahay et al.2014). Many EMEs show an increase in capital inflow, an increase in stock prices, a fall in sovereign debt yield, appreciation of currency and a rise in non-financial corporate debt (Lo Duca et al. 2014; Fratzscher et al. 2013). According to Yildirim (2016) between the early periods of crisis until May 2013, low risk aversion has occurred on global financial markets so that the UMP contributes to substantial capital inflows to EMEs. Glick and Leduc (2012) show that announcement of QE policy has reduced long-term interest rates and depreciation of US Dollar and British Pound.

However, in May 2013 US economy improved, so the Fed announced to apply Taper Tantrum policy (TT) such reduction of LSAP so it will reduce economic stimulus and then cause expectations of a tight money policy. During May 21 to December 31, 2013 there was a change in market sentiment that affected financial markets conditions in EMEs. Also there was a sharp increase in global risk aversion (Yildirim 2016). In TT period there was chaos (turmoil) on bonds, stocks, sovereign Credit Default Swaps (CDS) and foreign exchange markets in EMEs triggered by outflow portfolio(Mishra et al.2014;Sahay et al.2014).

The surge of capital inflow to EMEs during and immediate after GFC and reversely, surge of capital outflow after US economy recovery. This the same as happen in Latin American and Asia crises. Many researches have been done to investigate factors that determine sudden surge of inflow and outflow to and from EMEs. The previous studies such as Calvo et al. (1993); Fernandes-Arias (1996); Chuhan et al. (1998); Jeanneau and Micu (2002); Filler II (2004) remain a question whether push factors such as international economic growth, world interest rates, and global risk condition as external factors to drive or pull factors such as domestic financial conditions and economic fundamentals as internal factors to pull? To answer this we investigate by review of literature that related and focused on examining push and pull factors during GFC especially what specific dominant variable(s). We find that push factors as determinants of surge capital flow to EMEs during GFC, specifically world interest rate and global risk (risk appetite) are most dominant variables.

\section{Research Methodology}

The method used in this study is review of literature. We firstly investigate five previous literatures on Latin America and Asia crises and then focus on six main literatures that related to GFC such as researches done by Gonzales-Hermosillo (2008); Fratzscher (2012); Kim et al. (2013); Ahmed and Zlate (2014); Amstad et al. (2015); and Yildirim (2016).

\section{Results and Discussion}

There was growing literature discussed external factors (push factors) such as international interest rates, global economic growth, global risk conditions etc. and domestic factors (pull factors) such as macroeconomic fundamentals, structural reforms, etc. that were responsible for the increase in capital flows to EMEs. Following are review of researches done related to previous Latin America and Asia crises.

Calvo et.al (1993) focus only on external factors and discuss the characteristics of capital inflows into Latin America in period from 1978 to 1991 using Structural Vector Auto Regression model. They find that the decline in interest rates, continuing recession, and developments of US balance of payment have driven investors to shift capital to Latin America to look for new investment opportunities. It shows the importance of external factors that a reversal of these conditions may lead to a future capital outflow, increasing the macroeconomic vulnerability of Latin America economy.

Fernandes-Arias (1996) studies the determinants and sustainability of private capital inflows to 13 middleincome countries after 1989. Applying a structural model of international portfolio allocation in which the 
importance of country creditworthiness is made explicit. Fernandes-Arias (1996) questions whether these flows are mostly pulled by alternative domestic conditions or pushed by unfavorable conditions in AEs.it is found that the observed improvement in country creditworthiness is mostly due to the decline in international interest rates. Therefore its importance as a proximate cause does not support the "pull" Interpretation: the key answer in most countries that emerges is "push". This structural analysis is able to overcome some limitations of the push story in Calvo et al. (1993) where capital inflows in Latin America are proxied by changes in international reserves. Changes in reserves is poor proxy of capital inflows.

Chuhan et al. (1998) examine factors motivating the large capital flows to a number of EMEs. Using monthly US capital flows to 9 Latin America and 9 Asia countries to analyze the behavior of bond and equity flows. Using the two-stage least squares method (2SLS) on panel data, they find that although global factors such as the decline in US interest rates and slowdown in US industrial production are important in explaining capital inflows, country-specific developments are at least as important especially for Asia. Also it is found that equity flows are more sensitive than bond flows to global factors. But bond flows are generally more sensitive to a country's credit rating and secondary market debt price.

Jeanneau and Micu (2002) examine the role of push and pull factors in explaining bank lending to EMEs. Using the generalized least squares estimator based on panel data from 7 AEs as lenders and 10 EMEs as borrowers in period 1985-2000. They find that international lending seems to be affected by shifts in risk aversion in lending countries. The attitude of lenders towards risk is proxied by the risk premium on BBB-rated US corporate securities. A widening of the premium reflects greater risk aversion which is associated with a decline in lending flows. They find that both push and pull factors had a significant impact on international bank lending. However evidence concerning two of the most widely discussed push factors, namely real GDP and real interest rates in lending countries, shows that such variables exhibited a procyclical rather than a countercyclical influence on international bank lending. Stronger growth and higher short-term real interest rates in lending countries are associated with larger lending flows. Their findings concerning pull factors are broadly in line with those of other studies. Moreover, other factors such as the type of exchange rate regime, seem to have played an explanatory role. Additional tests show that fixed and tightly managed exchange rate regimes tend to encourage bank lending. While floating rates have an inhibiting influence. It also shows that carry trade strategies appear to have played a role in countries with tightly managed exchange rate regimes.

Filer II (2004) studies the causes and consequences of large capital inflows to South Korea during 1990s to see in their experience with large inflows matches the unusual developing economy story. Applying a structural model of a developing economy. The results: inflows to South Korea are largely a result of global shocks. However, unlike the experiences of Mexico and Latin American economies, Korean real money shocks are more important than global shocks at short-horizon and nearly as important at long-horizon. It concludes that the Korean experience is not entirely identical to the experience of a typical small open economy.

Next is the review on literature that analyzing push and pull factors during GFC. Gonzales-Hermosillo (2008) develops a structural vector auto-regression model to analyze the dynamics of bond spreads among a sample of mature and developing countries during periods of financial stress in the last decade (January 2, 1998 to August 9 , 2007). The model identifies and quantifies the contribution on bond spreads from global market conditions (including funding liquidity, market liquidity as well as credit and volatility risks), contagion effects and idiosyncratic factors. The results suggest that while idiosyncratic factors explain a significant amount of the changes in bond spreads over time, global financial market conditions are fundamental driving forces at times of crisis. The relative importance of the various global risk factors depend on the crisis episode. Contagion from emerging markets becomes small or non-existent when global financial market risks explicitly are taken into account. And Investors' risk appetite may be the key channel of transmission of shocks across nationalboundaries and market classes. So global financial market risk factors are important for all countries. 
Fratzscher (2012) uses a factor model on a broad data set of highly frequency portfolio capital flow of 50 countries include EMEs and AEs divided in 6 group of countries: Japan, US, Western Europe, Latin America, Asia and Pacific in the period of October 12, 2005 to November 12, 2010 to compare the relative importance of common shocks (push factors) and country-specific determinants (pull factors). It shows that common factors or push factors such as key crisis events, changes to global liquidity and risk conditions are more important overall as a driver of net capital flows for many countries in 2005-2007, as well as in particular during 2007-2008 financial crisis. However, in the recovery period since March 2009, common factors appear to have become less important drivers of global capital flow, where as it is domestic pull factors that have come to dominate in explaining capital flows, in particular for countries in emerging Asia and Latin America.

Kim et al.(2013) analyzes the determinants of international capital inflow into Korea during 1980-2000, in particular investigate the role of push (external) and pull (internal) factors in determining magnitude and direction of overall capital flows. Using regression (time series) analysis, the results show that external factor in particular world interest rate significantly affect overall capital flow into Korea. Among internal factor, current account has significant and negative effects on capital flow.

Ahmad and Zlate (2014) examine determinants of net private capital inflows to EMEs. Using regression on quarterly panel data set that covers 12 EMEs: 7 Asia countries and 5 Latin American countries, over the period from Q1 2002 to Q2 2013, they find that growth and interest rate differentials between EMEs and AEs and global risk appetite are statistically and economically important determinant of net private capital inflows.

Amstad et al. (2015) examine factors influencing investors in buying or selling sovereign bonds whether global risk factor or economic fundamentals by focusing on sovereign risk as reflected in monthly returns on credit default swap for 18 EMEs and 10 AEs. They divide the samples into three periods, old normal is between January 2004 to August 2008, global crisis is between September 2008 to April 2009 and new normal is between May 2009 to December 2014. Using regression analysis, the results are in old normal, global risk factors determine changes in sovereign CDS spreads by $51.1 \%$, while economic fundamentals determine only $15.1 \%$. In the new normal, global risk factors determine $63.9 \%$ and economic fundamentals determine only $8.7 \%$. In the global crisis, global risk factors determine $77.6 \%$ and economic fundamentals determine $13 \%$.

And Yildirim (2016) examines the effects of global financial conditions on asset markets in the fragile five economies (Brazil, Indonesia, India, Turkey and South Africa). Using a Structural Vector Auto Regression model with a block exogeneity procedure employing high-frequency daily data, from January 2, 2006 to August 31, 2015. Applying two external variables (external block) namely VIX index (the Chicago exchange market volatility index) which representing the global financial risk and The Fed funds target rate representing global interest rate. While the five domestic variables (domestic block) are 5-year government bond yields, 10-year government bond yield, 5-year sovereign CDS spreads, equity price, and exchange rate. The findings are global financial risk shocks have a significant effect on government bond yields, equity price, CDS spreads, and exchange rate in the fragile five. There are different effects to the fragile five and different effects depend also on the type of assets owned. The effect differences to these countries mostly depend on their macroeconomic fundamentals. Global financial risk shocks have an immediate effect on local currency bonds and CDS markets rather than on exchange rate and stock markets.

Furthermore, to support the above findings, followings are some researches that also done during or after GFC. Longstaff et al. (2011) who examine sovereign CDS spreads argue that sovereign credit can be related to global factors. Risk premia in CDS spread as compensation for bearing risk from global factors. Forbes and Warnock (2012) find that it is not usual case, a surge capital inflows to EMEs at the same time such as during the crisis. To explain this capital flow they state that global risk factors as measured by the VIX index are most important variables and domestic factors are less important. Aizenman et.al (2013) analyze CDS spreads in EME to find that external factors are more important before global crisis while domestic factors as capacity to adjust are 
more important during the crisis and after the crisis. Lane (2013) finds the initial recovery from 2010 to 2012 has been stronger for international capital flows to EMEs than to AEs. Rey (2013) finds there is a strong correlation of capital flows across different types and regions driven by a global financial cycle. Kennedy and Palerm (2014) test the premia by analyzing Emerging Market Bonds (EMBI) spreads, they find that the decrease in spreads from 2002 to 2007 reflects the improvements in country-specific fundamentals, but there is a sharp increase in spreads in the 2008 crisis due to risk aversion. Lane (2015) finds for a sample of low income countries that the role of economic fundamentals in explaining the cross-country variations in international financial flows changes over time such that macroeconomic variables associated with inflows in one period may be correlated with outflow in another period. Barroso et al. (2015) find the UMP has an effect on capital inflows to Brazil and through this channel, there is economic improvement and financial stability in Brazil.

\section{Conclusions}

From above results we may summarize as follows. Based on previous studies on Latin America and Asian crises, Calvo at al. (1993) find decline interest rate, continuing regression and development of US BOP (push) are dominant factors. Fernandes-Arias finds the decline in international interest rate (push) as dominant factor, while Chuhan et al. (1998) find the decline in US interest rate and slowdown in US industrial production (push) are as important as country-specific developments (pull). Moreover Jeanneau and Micu (2002) find stronger growth and higher short-term real interest rates in lending countries (push) cause larger lending flow, but tightly managed exchange rate regime (pull) encourage bank lending. Filler II (2004) finds Korean real money shocks (pull) are more important than global shocks (push) at short-run horizon, but nearly as important as global shocks at long -horizon.

From above facts we may conclude that push factors and pull factors have the same role. However, based on researches during GFC, the most dominant factors are world interest rate and global risk variables, shown by researches such as Gonzales-Hermosillo (2008) finds global market risk factors are fundamental driving forces during period of crisis. Fratzscher (2012) finds common factors: key crisis events, changes to global liquidity, and risk condition are important drivers of net capital flow during 2007-2008 financial crisis. Kim et al. (2013) find world interest rate significantly affect overall capital flow to Korea. Ahmed and Zlate (2014) find growth and interest differentials and global risk condition are key determinant (push) so UMP is an important determinant of capital inflow to EMEs. Amstad et al. (2015) find global risk is very influential and very dominant in determining sovereign CDS spreads. Yildirim (2016) finds global financial risk shocks have significant effects on financial condition and asset markets.

We may conclude that push factors are determinant factors and world interest rate and global risk appetite are dominant variables. We may say during financial crisis although push factors are as important as pull factors, but in general, push factors are more dominant than pull factors. Furthermore every financial crisis frequently occurs the surge of capital inflows to emerging markets during the crisis and reversely, the surge of capital outflows to advanced economies after global economy recovery.

This research, however, is subject to several limitations. These researches mainly focused on world interest rate which represented by US federal funds rate as push or dominant factor while the important interest rate of emerging markets as pull or dependent factor haven't included yet in the study. This study of factors influencing capital flow from AEs to EMEs during financial crisis should cover not only world interest rate (US federal funds rate) as external factor but also emerging market interest rate as domestic factor. Therefore further research should pay attention on this factor. 


\section{References}

Ahmed, S., Zlate, A. 2014, Capital Flows to Emerging Market Economies: A Brave New World? Journal International Money Finance 48, 221-248.

Ainzenman, J., Jinjarak, Y., and Park, D., 2013, Fundamentals and Sovereign Risk of Emerging Markets. Working Paper, NBER 18963.

Amstad, M., Remolona, E., and Shek, J., 2015, How do Global Investors Differentiate Between Sovereign Risk? The New Normal Versus The Old. Journal of International Money and Finance Vol. 66, 32-48.

https://doi.org/10.1016/j.jimonfin.2015.12.006

Barroso, J. B. R. B., Silva, L. A. P, and Sales, A. S., 2015, Quantitative Easing and Related Capital Flows into Brazil: Measuring Its Effects and Transmission Channel Through A Rigorous Counterfactual Evaluation. Journal of International Money and Finance.

Bremus, F., Fratzscher, M., 2015, Drivers of Structural Change in Cross-border Banking Since The Global Crisis. Journal International Money Finance 52, 32-59.

Bussiere, M., Schmidt, J., and Valla, N., 2016, International Financial Flows in The New Normal: Key Patterns (and Why We Should Care). CEPII Policy Brief 2016-10.

Calvo, G. A., Leiderman, L., and Reinhart, C. M., 1993, Capital Inflows to Latin America: The Role of External Factors. International Monetary Fund Staff Papers 40 (1), 108-151.

Cerutti, E., Claessens, S., and Puy, D., 2015, Push Factors and Capital Flows to Emerging Markets: Why Knowing Your Lender Matters More than Fundamentals. Working Paper, IMF/WP/15/127.

Chuhan, P., Claessens, S., ad Mamingi, N., 1998, Equity and Bond Flows to Latin America and Asia: The Role of Global and Country Factors. Journal of Development Economics 55, 439-463.

Fernandez-Arias, E., 1996, The New Wave of Private Capital Inflows: Push or Pull? Journal of Development Economies 48 (2), 389-418.

Filer II, L. H., 2004, Large Capital Inflows to Korea: The Traditional Developing Economy Story? Journal of Asian Economics 15 (1), 99-110.

Forbes, K., and Warnock, F., 2012, Capital Flow Waves: Surges, Stops, Flight and Retrenchment. Journal of International Economies 88, 235-251.

Fratzcher, M., 2012, Capital Flows, Push Versus Pull Factors at The Global Financial Crisis. Journal of International Economics 88, 341-356.

Fratzscher. M., Duca, M.L., and Straub, R. 2013, On The International Spillovers of US Quantitative Easing. Working Paper, ECB 1557.

Glick, R., Leduc, S., 2012, Central Bank Announcements of Asset Purchases and The Impact on Global Financial and Commodity Markets. Journal of International Money and Finance Vol. 31: 2078-2101.

Gonzalez-Hermosillo, B., 2008, Investor's Risk Appetite and Global Financial Market Conditions. IMF/WP/08/85.

IMF, 2016, Understanding The Slowdown in Capital Flow to Emerging Markets. IMF World Economic Outlook April 2016, Chapter 2.

Jeanneau, S., Micu, M., 2002, International Bank Lending to Emerging Market Countries: Explaining The 1990s Roller Coaster. BIS Quarterly Review, 52-64.

Kennedy, M., Palerm. A., 2014, Emerging Market Bond Spreads: The Role of Global and Domestic Factors from 2002 to 2011. Journal of International Money and Finance 43, 70-87.

Kim, S., Kim S., and Choi, Y., 2013, Determinants of International Capital Flows in Korea: Push vs. Pull Factors. Korean and The World Economy, vol 14, No 3 (December 2013), 447-474.

Lane, P.R., 2013, Financial Globalization and The Crisis. Open Economic Review 24, 555-580.

Lane, P.R., 2015, International Financial Flows in Low-income Countries. Pacific Economic Review. 20, 49-72.

Lo Duca, M., Nicoletti, G., and Martinez, A.V., 2014, Global Corporate Bond Issuance: What Role for US Quantitative Easing? Working Paper, ECB 1649. 
Longstaff, F. A., Pan, J., Pedersen, L. H., Singleton, K. J., 2011, How Sovereign is Sovereign Credit Risk? American Economic Journal: Macroeconomics.

Milesi-Ferretti, G. M., Tille, C., 2011, The Great Retrenchment: International Capital Flows during The Global Financial Crisis. Economic Policy 26, 289-346.

Mishra, P., Moriyama, K., N'Diaye, P., and Nguyen, L., 2014, Impact of Fed Tapering Announcements on Emerging Markets. Working Paper, IMF 14/109.

Rey, H., 2013, Dilemma Not Trilemma: The Global Financial Cycle and Monetary Policy Independence. Federal Reserve Bank of Kansas City Economic Policy Symposium 2013.

Saghian, S., Reed, M., 2015, Spillover Effect of The US Federal Reserve's Recent Quantitative Easing on Canadian Commodity Prices. International Journal of Food and Agriculture Economies Vol. 3 No. 1, 33-43.

Sahay, R., Arora, V., Arvanitis, T., Faruqee, H., N'Diaye, P., Mancini-Griffoli, T., and an IMF Team, 2014, Emerging Market Volatality: Lessons from The Taper Tantrum. IMF Staff Discussion Note, SDN/14/09.

Yildirim, Z., 2016, Global Financial Conditions and Asset Markets: Evidence from Fragile Emerging Economies. Economic Modelling 57, 208-220. 